\title{
The first record of the genus Dipteranthus (Orchidaceae) in the Guyana, description of a new species
}

\author{
Dariusz L. Szlachetko, Monika M. Lipińska \& Iwona Skorowska*
}

Department of Plant Taxonomy and Nature Conservation, Faculty of Biology, University of Gdańsk, Wita Stwosza 59, 80-308 Gdańsk, Poland

* corresponding author (e-mail: iwona.skorowska@biol.ug.edu.pl)

\begin{abstract}
The orchid genus Dipteranthus, described by Rodrigues in 1882, comprises about 10 species distributed from Venezuela to Bolivia and Brazil. Plants of Dipteranthus are small epiphytes, reaching in total up to $10 \mathrm{~cm}$ in length, hence, are easily overlooked in the field. Modern classification of Dipteranthus is still under discussion. During the revision of orchids of the Guianas, we came across some specimens that do not match morphological characters of any previously known Dipteranthus species. Thus, we propose that these specimens represent a new species - Dipteranthus clarkei sp. nov. D. clarkei is the first representative of the genus known from Guyana.
\end{abstract}

Key words: Dipteranthus, Guyana, Orchidaceae, orchids, taxonomy

The orchid genus Dipteranthus Barb.Rodr. comprises about 10 species distributed from Venezuela to Bolivia and Brazil, where the greatest diversity of these orchids is noted. This genus was firstly described by João Barbosa Rodrigues in 1882. At that time, it included only one species - D. pseudobulbiferus (Barb.Rodr.) Barb. Rodr. (三Ornithocephalus pseudobulbiferus Barb.Rodr.).

Plants of Dipteranthus are small epiphytes, reaching in total up to $10 \mathrm{~cm}$ in length, hence, are easily overlooked in the field. Pseudobulb is small, 1-nodial, terminated with a single leaf and concealed basally by 2-6 leafy sheaths. Leaf and sheaths are coriaceous, bifacial, with articulate petiolate. Inflorescence is lateral, unbranched, usually longer than leaves, 1-15-flowered, with erect to fractiflex rachis. Flowers are small, resupinate, spurless, with some parts green, white to cream, or yellowish green. Sepals are free, equal to or smaller than petals in size and shape. Lip is unlobed, firmly connate with the gynostemium base, flat to cochleate. The lip callus is very characteristic at the species level, and can be green to orange. Elongated gynostemium is gently arched or sigmoid, delicate, with column part winged in the basal half, attenuate towards the apex (Szlachetko \& Mytnik-Ejsmont 2009).

In 1887, Pfitzer combined Dipteranthus with Diplostylis Sond., Platyrhiza Barb.Rodr. and Centroglossa Barb.Rodr. and transferred them to one diverse taxon
Zygostates Lindl.. In 1915, Schlechter separated Dipteranthus as a distinctive genus and classified it within Onciidiinae Benth.. Modern classification of Dipterantus is still under discussion. Over the years, many taxonomists treated Dipteranthus and Zygostates as separate genera (Dressler 1993; Szlachetko 1995; Toscano de Brito 2001). Molecular data, however, indicated that this genus could be embedded within Zygostates s.l. (Williams et al. 2005; Chase \& Toscano de Brito 2009; Pridgeon et al. 2009; Neubig et al. 2012). Nevertheless, these two genera can be easily distinguished by the presence or absence of pseudobulbs, beaked anther, as well as the different types of leaves. Such incongruence between results of molecular and morphological studies is often met in orchids. In our opinion, the taxonomic status of both genera require further study.

During the revision of orchids of the Guianas, we came across some specimens that do not match morphological characters of any previously described Dipteranthus representative. Thus, we propose that these specimens are recognized as a new species. This is the first, and so far the only, species of Dipteranthus known from this area.

Dipteranthus clarkei Szlach., Lipińska \& Skorowska, sp. nov. (Fig. 1). Type: GUYANA, Potaro-Siparuni Region. Clarke 10137 \& al. (holotype: US 36663316!, UGDA-DLSz! - drawing). 

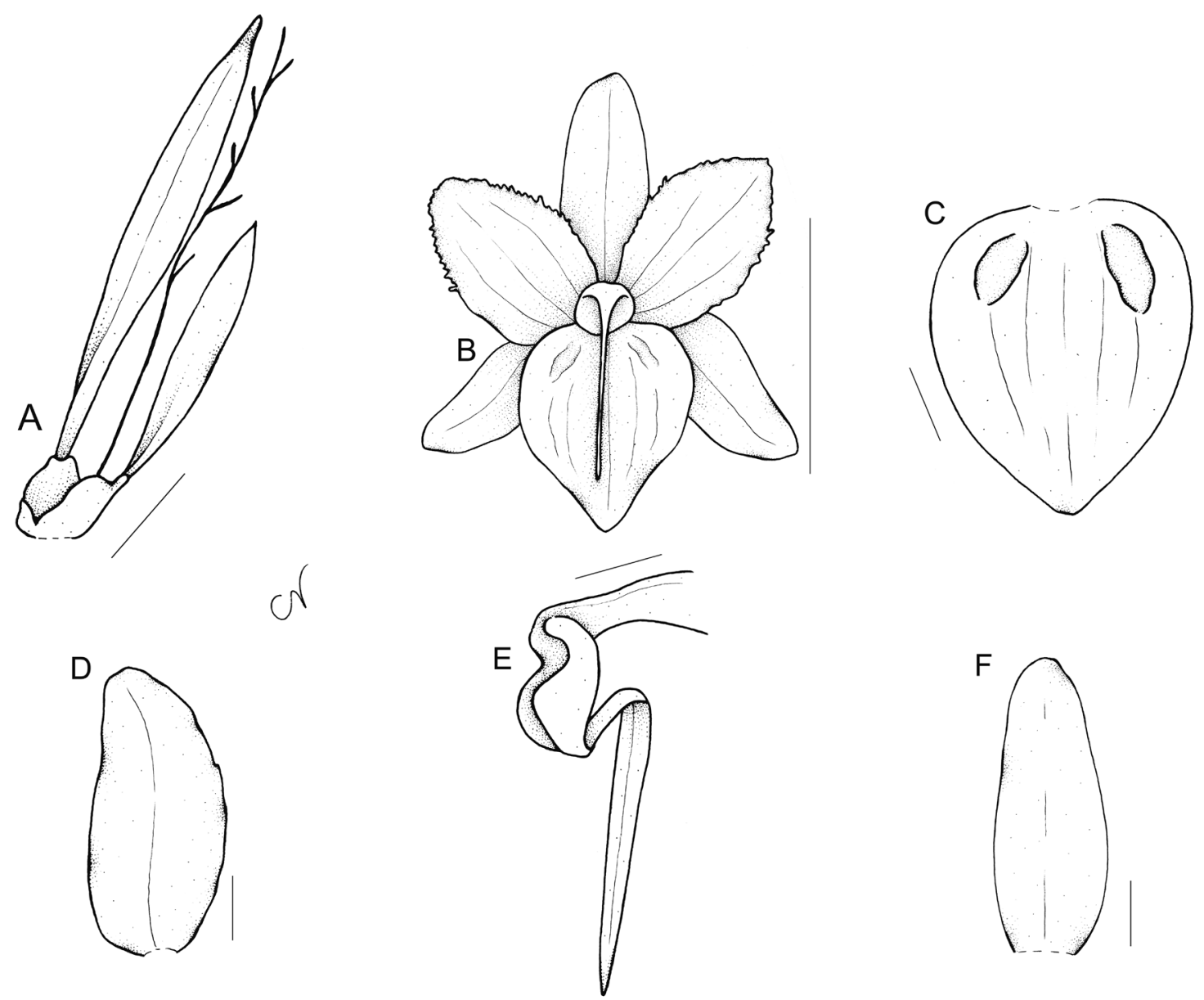

Fig. 1. Dipteranthus clarkei sp. nov. - habitat and dissected flower

Explanations: A - habit, scale bar $=5 \mathrm{~mm} ; \mathrm{B}-$ flower, scale bar $=5 \mathrm{~mm} ; \mathrm{C}-$ lip, scale bar $=1 \mathrm{~mm} ; \mathrm{D}-$ lateral sepal, scale bar $=1 \mathrm{~mm} ; \mathrm{E}-\mathrm{gynostemium}$, scale bar $=1 \mathrm{~mm} ; \mathrm{F}-$ dorsal sepal, scale bar $=1 \mathrm{~mm}$. Drawn from the holotype

De s cription: Plants small. Pseudobulbs $4 \mathrm{~mm}$ long, ca $1.5 \mathrm{~mm}$ in diameter, oblong ovoid, somewhat compressed, unifoliate. Leaf $45 \mathrm{~mm}$ long, ca $4 \mathrm{~mm}$ wide, narrowly oblanceolate, subacute, coriaceous, bifacial, erect. Pseudobulb concealed basally by 2 leafy sheaths, somewhat shorter and narrower than leaf. Inflorescence lateral, up to $60 \mathrm{~mm}$ long, rather laxly 10-flowered, rachis winged. Flowers small, resupinate, campaulate. Floral bracts ca $2 \mathrm{~mm}$ long. Pedicellate ovary ca $7 \mathrm{~mm}$ long. Dorsal sepal $5.1 \mathrm{~mm}$ long, $1.6 \mathrm{~mm}$ wide, oblong elliptic to oblong elliptic-ovate, rounded at apex, somewhat concave in the centre, glabrous, 1-veined. Petals $4.5 \mathrm{~mm}$ long, $2.8 \mathrm{~mm}$ wide, elliptic-ovate, obtuse, margins irregularly denticulate-fimbriate, otherwise glabrous, 3-veined. Lateral sepals $4.5 \mathrm{~mm}$ long, $1.4 \mathrm{~mm}$ wide, similar to form to the dorsal sepal, but somewhat falcate, margins more or less erose, 1-veined. Lip 3.8$4 \mathrm{~mm}$ long, 3-3.2 mm wide, broadly elliptic-ovate in outline, somewhat concave, obtuse at apex, base broadly cuneate, 5 -veined, with lateral veins branching. Lip callus consisting of two, fleshy, somewhat thickened pads along basal third of lateral veins. Gynostemium 2 $\mathrm{mm}$ long, slender, apically swollen. Rostellum $3 \mathrm{~mm}$ long, sigmoidally bent at the base, narrow, acute at the apex.

Distribution and habitat: The genus Dipteranthus has never been reported so far from the Guianas region. The most widespread species of the genus, D. planifolius (A. Rich.) Garay, was mentioned by Carnevali \& Ramirez-Morillo (2003) to occur in Venezuelan Guayana, i.e., an area adjacent to Guyana. This species is the most widespread in the whole genus and was recorded so far from Venezuela, Colombia, Ecuador, Peru, Bolivia and Brazil.

Etymology: Dedicated to the collector of the type specimen.

Tax o n o mi c notes: We compared our finding with $D$. planifolius and found differences that in our opinion justify the separation of $D$. clarkei as a new species. Both species share similar habit and size, what can result in their misidentification. The lip of $D . p l-$ anifolius is oblong elliptic, more or less as wide at the base as at the apex (vs broadly elliptic-ovate, widest at the base in $D$. clarkei), and adorned with single, fleshy 
callus occupying its basal area (vs two, fleshy, well separated, somewhat thickened pads along basal third of lateral veins in the new species). Petals of $D$. planifolius are almost as long as wide (vs over 1.5 times longer than wide) with erose margins (vs margins irregularly denticulate-fimbriate). It is noteworthy that rostellum of D. planifolius is gently upcurved from the base, whereas in D. clarkei - it is basally sigmoid, and erect above. All these aforementioned characters separate $D$. clarkei from D. planifolius and make the former easily recognizable.

Acknowledgements. Authors are grateful to the curators of the US and AMES herbaria for their kind assistance during our visits and for conducted studies and Natalia Olędrzyńska for preparing the line drawings.

\section{References}

Carnevali G. \& Ramirez-Morillo I. 2003. Dipteranthus. In: J. A. Steyermark, P. E. Berry, K. Yatskievich \& B. K. Holst (eds.). Flora of the Venezuelan Guyana, Vol. 7, 307 pp. Missouri Botanical Garden Press, St. Louis.

Chase M. W. \& Toscano de Brito A. L. V. 2009. Zygostates. In: A. M. Pridgeon, P. Cribi, M. W. Chase \& F. N. Rasmussen (eds.). Genera Orchidacearum: Epidendroideae, Vol. 5, 391-394 pp. Oxford University Press, Oxford.

Dressler R. L. 1993. Phylogeny and Classification of the Orchid Family. Dioscorides Press, Portland.

Neubig K. M., Whitten W. M., Williams N. H., Blanco M. A., Endara L., Burleigh J. G., Silvera K., Cushman J. C. \& ChASE M. W. 2012. Generic recircumscriptions of Oncidiinae (Orchidaceae: Cymbidieae) based on maximum likelihood analysis of combined DNA datasets. Bot J Linn Soc 168: 117-146.

Pfitzer E. H. H. 1887. Entwurf einer natürlichen Anordnung der Orchideen. Carl Winter, Heidelberg.
Pridgeon A. M., Cribi P. J., Chase M. W. \& Rasmussen F. N. 2009. Genera Orchidacearum. Epidendroideae (Part Two). Vol. 5. Oxford University Press, Oxford.

Rodrigues J. B. 1882. Genera et Species Orchidearum Novarum. Vol 2. Typographia Nacional, Rio de Janeiro.

SCHLEChter R. 1915. Die Orchideen: ihre Beschreibung, Kultur und Züchtung. Handbuch für Orchideenliebhaber, Züchter und Botaniker. P. Parey, Berlin.

Szlachetкo D. L. \& Mytnik-Ejsmont J. 2009. Gynostemia Orchidalium. Vol. 1. Acta Bot. Fennica. 180: 1-313.

SzlachetKo D. L. 1995. Systema Orchidalium. Fragm. Flor. Geobot. Suppl. 3: 1-137.

Toscano de Brito A. L. V. 2001. Systematic review of the Ornithocephalus Group (Oncidiinae; Orchidaceae) with comments on Hofmeisterella. Lindleyana 16(3): 157-217.

Williams N. H., Whitten W. M. \& Dressler R. L. 2005. Molecular systematics of Telipogon (Orchidaceae: Oncidiinae) and its allies: nuclear and plastid DNA sequence data. Lankesteriana 5: 163-184. 